\title{
Distinct Effects of Bosentan on NO-Dependent Vasodilation and Calcium Influx in Heterozygous Ren-2 Transgenic Rats on High-Salt Diet
}

\author{
I. VANĚČKOVÁ ${ }^{1}$, S. HOJNÁ ${ }^{1}$, M. KADLECOVÁ ${ }^{1}$, E. KOMPANOWSKA-JEZIERSKA ${ }^{2}$, \\ J. ZICHA ${ }^{1}$
}

${ }^{1}$ Department of Experimental Hypertension, Institute of Physiology of the Czech Academy of Sciences, Prague, Czech Republic, ${ }^{2}$ Mossakowski Medical Research Centre, Polish Academy of Sciences, Warsaw, Poland

Received April 17, 2019

Accepted May 27, 2019

Epub Ahead of Print August 19, 2019

\section{Summary}

Our studies in hypertensive Ren-2 transgenic rats (TGR) demonstrated that chronic administration of atrasentan $\left(E T_{A}\right.$ receptor antagonist) decreased blood pressure by reduced $\mathrm{Ca}^{2+}$ influx through L-type voltage-dependent calcium channels (L-VDCC) and attenuated angiotensin II-dependent vasoconstriction. We were interested whether bosentan (nonselective $\mathrm{ET}_{\mathrm{A}} / \mathrm{ET}_{\mathrm{B}}$ receptor antagonist) would have similar effects. Young 4-week-old (preventive study) and adult 8-weekold (therapeutic study) heterozygous TGR and their normotensive Hannover Sprague-Dawley (HanSD) controls were fed normal-salt (NS, $0.6 \% \mathrm{NaCl}$ ) or high-salt (HS, $2 \% \mathrm{NaCl}$ ) diet for 8 weeks. An additional group of TGR fed HS was treated with bosentan (100 mg/kg/day). Bosentan had no effect on BP of TGR fed highsalt diet in both the preventive and therapeutic studies. There was no difference in the contribution of angiotensin II-dependent and sympathetic vasoconstriction in bosentan-treated TGR compared to untreated TGR under the condition of high-salt intake. However, bosentan significantly reduced NO-dependent vasodilation and nifedipine-sensitive BP component in TGR on HS diet. A highly important correlation of nifedipine-induced BP change and the BP after L-NAME administration was demonstrated. Although bosentan did not result in any blood pressure lowering effects, it substantially influenced NO-dependent vasodilation and calcium influx through L-VDCC in the heterozygous TGR fed HS diet. A significant correlation of nifedipine-induced BP change and the BP after L-NAME administration suggests an important role of nitric oxide in the closure of L-type voltage dependent calcium channels.

\section{Key words}

Hypertension • Bosentan • Vasoactive systems • Blood pressure regulation

\section{Corresponding author}

I. Vaněčková, Department of Experimental Hypertension, Institute of Physiology of the Czech Academy of Sciences, Vídeňská 1083, CZ 142 20, Prague 4, Czech Republic. E-mail: ivana.vaneckova@fgu.cas.cz

\section{Introduction}

Ren-2 transgenic rat (TGR) is a typical model of angiotensin II-dependent hypertension in which the insertion of the mouse renin- 2 gene into the genome of Hannover Sprague Dawley (HanSD) rats is associated with high blood pressure (Mullins et al. 1990). Our previous study demonstrated that the contribution of distinct vasoactive systems regulating blood pressure is age- and strain-dependent. Thus, RAS-dependent vasoconstriction is higher in homozygous rats and its role declines with the age of animals in both strains. By contrast, the sympathetic component of BP is more pronounced in adult rats (Vaněčková et al. 2012).

Our interest was focused on the mechanisms by which different antihypertensive drugs affected blood pressure in this experimental model of hypertension. We have demonstrated that the chronic treatment of TGR animals with three different types of RAS blockers 
(angiotensin receptor type 1 blockers, angiotensin converting enzyme inhibitors or direct renin inhibitors) similarly normalized their blood pressure; this effect being mediated mainly by the substantially attenuated RAS-dependent and partly by moderately reduced sympathetic vasoconstriction. When atrasentan (ET $\mathrm{E}_{\mathrm{A}}$ receptor antagonist) was added to these RAS blockers, it did not influence the BP and hence the major vasoactive systems. However, it substantially decreased nifedipine-sensitive calcium influx through voltagedependent calcium channels (Vaněčková et al. 2016). A similar reduction of calcium influx was also demonstrated in a study evaluating the effects of $\mathrm{ET}_{\mathrm{A}}$ receptor blockade alone showing a four-fold decrease of this parameter in heterozygous TGR on a high-salt diet. Moreover, the blood pressure lowering effect of atrasentan was also associated with a substantial attenuation of angiotensin II-dependent vasoconstriction. Of note was the attenuation of nitric oxide-dependent vasodilation which was not accompanied by a compensatory activation of other vasodilator systems (BK $\mathrm{BK}_{\mathrm{Ca}}$ channels or vasodilator prostanoids) (Vaněčková et al. 2015).

There is some controversy on the superiority of the selective $\mathrm{ET}_{\mathrm{A}}$ over the nonselective (dual) $\mathrm{ET}_{\mathrm{A}} / \mathrm{ET}_{\mathrm{B}}$ receptor blockade. Some authors favor the selective $\mathrm{ET}_{\mathrm{A}}$ blockers due to their antihypertensive, anti-inflammatory and antiproliferative effects, while others prefer the use of dual $\mathrm{ET}_{\mathrm{A}} / \mathrm{ET}_{\mathrm{B}}$ endothelin receptor blockers (Vaněčková et al. 2018). Our studies in Ren-2 transgenic rats have shown that atrasentan decreased blood pressure and reduced cardiac hypertrophy in both young and adult heterozygous as well as homozygous TGR. Similarly, the positive effects on blood pressure and organ protection of selective $\mathrm{ET}_{\mathrm{A}}$ blockers were found in salt-loaded stroke-prone SHR (Okada et al. 1995), Dahl salt-sensitive rats (Barton et al. 1998, Okada et al. 2000), DOCA-salt rats (Allcock et al. 1998, Matsumura et al. 1999), and Sabra rats (Rothermund et al. 2003). By contrast, none of our studies with mixed $\mathrm{ET}_{\mathrm{A}} / \mathrm{ET}_{\mathrm{B}}$ endothelin receptor blockade in TGR demonstrated the lowering of blood pressure, although bosentan had positive effects on their survival and exerted slight renoprotective effects in some studies (Dvořák et al. 2004, Opočenský et al. 2004, Vaněčková et al. 2005, Vaněčková et al. 2006, Opočenský et al. 2006, Vernerová et al. 2008). The beneficial organoprotective effects of the nonselective ET receptor blockade were also found in rats with diabetic nephropathy (Ding et al. 2003) and in double transgenic rats (Muller et al. 2000). Moreover, the hypotensive effects of the nonselective ET receptor blockade were demonstrated in the Goldblatt $2 \mathrm{~K} 1 \mathrm{C}$ model (Li et al. 1996), DOCA-salt hypertensive rats (Schiffrin et al. 1996), double transgenic rats (Muller et al. 2000) and young TGR (Rossi et al. 2000).

Many experimental studies support the idea that young animals are more sensitive to various pharmacological interventions (Zicha et al. 1986, Zicha and Kuneš 1999). Not surprisingly, the therapies applied at a younger age (preventive treatment) are usually more effective than those in animals with established hypertension (therapeutic treatment). Interestingly, one of the exceptions from this general rule is the study of Zicha et al. (2012) which demonstrated that ambrisentan (ET $\mathrm{A}_{\mathrm{A}}$ receptor antagonist) was more effective in reducing the blood pressure of adult young salt-sensitive Dahl rats compared to young ones (Zicha et al. 2012).

Endothelin-1 production is enhanced during increased salt intake; this occurs in the renal collecting duct, specifically the inner medullary collecting duct (IMCD), which upon stimulation by high salt intake produces ET-1 to promote the elimination of salt load by autocrine inhibition of $\mathrm{Na}^{+}$reabsorption (Kohan et al. 2011). Moreover, Herrera et al. (2005) reported that with a high salt intake, medullary tonicity increased - this process being associated with the activation of $\mathrm{ET}_{\mathrm{B}}$ receptors, which leads to enhanced eNOS activity, NO production and inhibition of $\mathrm{Na}^{+}$transport in renal thick ascending limb in vitro.

Therefore, we were interested (i) whether bosentan could have some effects on the major vasoactive systems contributing to BP maintenance, and (ii) whether nonselective endothelin receptor blockers might, similar to selective $\mathrm{ET}_{\mathrm{A}}$ receptor blockade, affect the NO-dependent vasodilation and calcium influx through the voltage-dependent calcium channels.

\section{Methods}

\section{Ethics statement}

All the procedures and experimental protocols were approved by the Ethical Committee of the Institute of Physiology, Czech Academy of Sciences (Protocol Nr. 139/2013), and conform to the European Convention on Animal Protection and Guidelines on Research Animal Use (Directive 2010/63/EU). 


\section{Animals and in vivo experimental strategies}

Four-week-old young (prevention study) or 8-week-old adult (therapeutic study) male heterozygous (mRen-2) 27 transgenic rats (TGR) and their transgenenegative control Hannover Sprague Dawley (HanSD) rats were housed at $23{ }^{\circ} \mathrm{C}$ under a $12 \mathrm{~h}$ light/dark cycle, given a normal salt diet $(0.6 \% \mathrm{NaCl})$ or high-salt diet $(2.0 \%$ $\mathrm{NaCl}$ ) and tap water ad libitum for 8 weeks. The additional group of TGR fed a high-salt diet was treated with bosentan, which was mixed to the diet (100 mg/kg/day).

All rats used in this study were bred at the Institute of Clinical and Experimental Medicine from stock animals supplied by the Max Delbrück Center for Molecular Medicine in Berlin, Germany.

After 8 weeks of treatment, the involvement of major vasoactive systems (RAS, SNS and NO) contributing to blood pressure regulation was determined. Additionally, the calcium influx through the L-type voltage-dependent calcium channel (L-VDCC) was evaluated after the complete blockade of major vasoactive systems. One day prior to the experiment, the cannulation of the carotid artery (PE 50) and the jugular vein (PE 10) was performed under $2.5 \%$ isoflurane anesthesia to enable BP measurement and the infusion of drugs, respectively. The cannulae were exteriorized in the interscapular region. Blood pressure and heart rate (HR) were recorded using a pressure transducer and a multichannel recorder (ADInstruments, Bella Vista, Australia) employing the modified protocol of Minami et al. (1995). Briefly, rats were adapted in transparent plastic cages for $30 \mathrm{~min}$. Then, the RAS blockade with captopril $(10 \mathrm{mg} / \mathrm{kg})$ was followed by the ganglionic blockade of SNS with pentolinium $(5 \mathrm{mg} / \mathrm{kg}) 15 \mathrm{~min}$ later. After NO synthase inhibition with L-NAME $(30 \mathrm{mg} / \mathrm{kg})$, the BP was monitored for a further $20 \mathrm{~min}$. Finally, the L-type voltage-dependent calcium channel blocker nifedipine $(0.4 \mathrm{mg} / \mathrm{kg})$ was administered. The BP levels before and after particular blockades were determined and the respective BP changes were calculated. All drugs were dissolved in saline and administered as intravenous bolus injections in a volume of $1 \mathrm{ml} / \mathrm{kg}$ of body weight. At the end of the experiment the rats were euthanized by anesthetic overdosage and their hearts and kidney were weighed.

\section{Drugs}

All drugs were purchased from Sigma (St. Louis, Missouri, USA) except for bosentan (a contribution from
Martine Clozel, Actellion).

\section{Statistical analysis}

The results are expressed as the mean \pm SEM. The statistical differences were evaluated by one-way and two-way analysis of variance (ANOVA) (Instat, La Jolla, California, USA) followed by the Fisher LSD post hoc test. $\mathrm{P}<0.05$ values were considered to be statistically significant.

\section{Results}

The blood pressure of TGR animals on a normal salt diet was significantly elevated compared to normotensive HanSD rats in both the prevention and therapeutic studies (Fig. 1). The BP difference was more pronounced in young animals than in adults $(181 \pm 5 \mathrm{~mm} \mathrm{Hg}$ vs. $156 \pm 5 \mathrm{~mm} \mathrm{Hg})$. The feeding of a high-salt diet had no effect on the BP in either HanSD rats or TGR in both studies. However, it increased the relative kidney weights in TGR rats in both studies and cardiac hypertrophy in TGR in the prevention study (Table 1). Bosentan did not exert any effect on BP or body parameters in TGR.

The contribution of Ang II-dependent vasoconstriction was proportional to basal BP level being four-fold higher in young TGR in the prevention study while only two-fold higher in adult TGR in the therapeutic study (Fig. 2A, D). By contrast, although the sympathetic vasoconstriction substantially contributed to the increased BP in both age groups of TGR, its contribution was greater in adult TGR (Fig. 2B, E). No effects of a high-salt diet or bosentan on angiotensin IIdependent or sympathetic vasoconstriction were found.

NO-dependent vasodilation was not different between TGR and control HanSD animals in either study (Fig. 2C, F). In addition, the high-salt diet had no effect on this parameter in hypertensive or normotensive rats. On the other hand, bosentan significantly lowered NO-dependent vasodilation in both the prevention and therapeutic studies. This was also true for nifedipinesensitive BP reduction elicited by the inhibition of calcium influx through the voltage-dependent calcium channels (Fig. 3). Moreover, we analyzed the relationship between the MAP measured after NO synthase inhibition with L-NAME and nifedipine-sensitive BP change and we found a highly significant correlation of these parameters in both the prevention and therapeutic studies (Fig. 4A, B). 

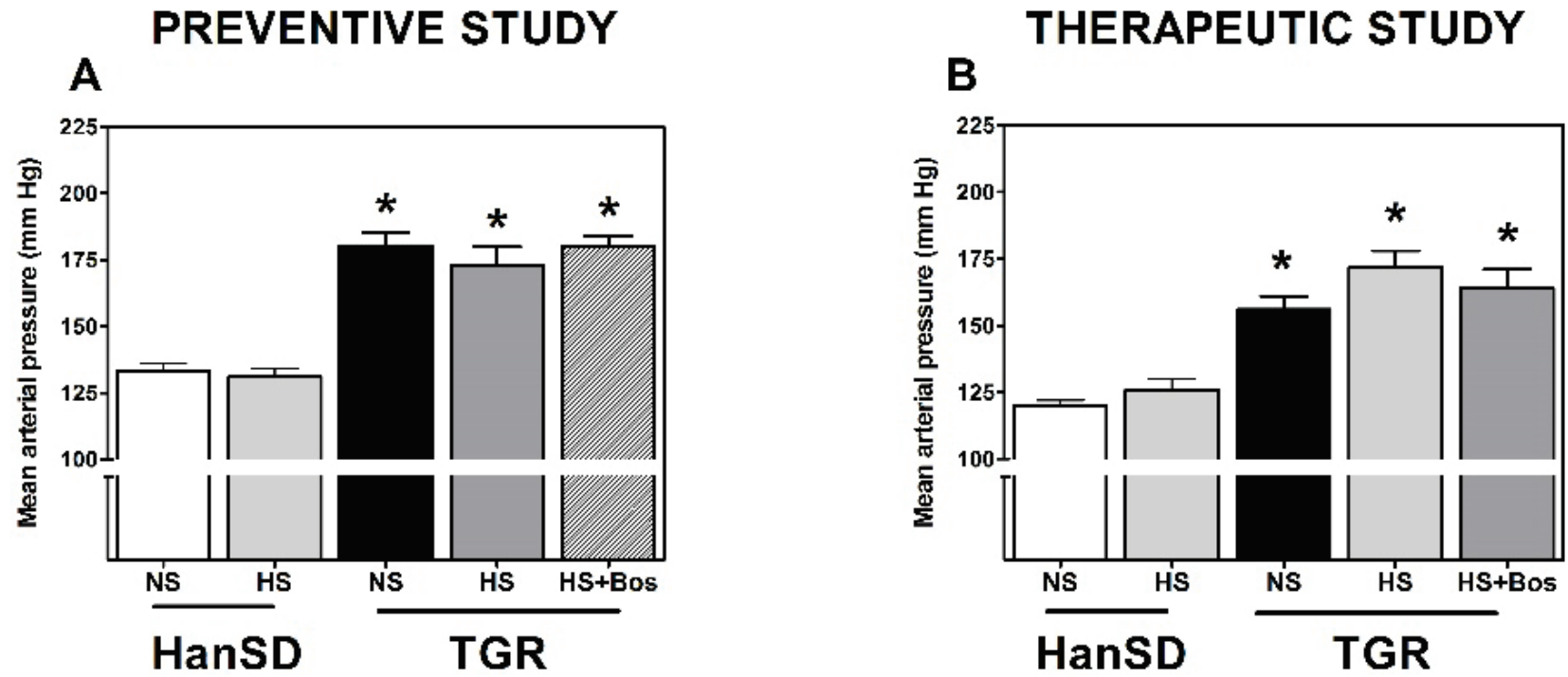

Fig. 1. The blood pressure of young (preventive study)(A) and adult (therapeutic study)(B) normotensive control Hannover Sprague Dawley (HanSD) and hypertensive heterozygous Ren-2 transgenic rats (TGR) on normal salt (NS) diet, high-salt (HS) diet, or HS treated with nonselective $\mathrm{ET}_{\mathrm{A}} / \mathrm{ET}_{\mathrm{B}}$ receptor antagonist bosentan (Bos) measured at the end of the study. The data are the means $\pm \mathrm{SEM}$. $* \mathrm{p}<0.05$, vs. control HanSD rats.

Table 1. Body and organ weights in young (preventive study) and adult (therapeutic study) normotensive control Hannover Sprague Dawley (HanSD) and hypertensive heterozygous Ren-2 transgenic rats (TGR) on normal salt (NS) diet, high-salt (HS) diet, or HS treated with nonselective $\mathrm{ET}_{\mathrm{A}} / \mathrm{ET}_{\mathrm{B}}$ receptor antagonist bosentan.

\section{PREVENTIVE STUDY}

\begin{tabular}{|c|c|c|c|c|c|}
\hline & HanSD-NS & HanSD-HS & TGR-NS & TGR-HS & $\begin{array}{l}\text { TGR-HS- } \\
\text { bosentan }\end{array}$ \\
\hline Number of rats & 7 & 7 & 10 & 12 & 9 \\
\hline Body weight (g) & $408 \pm 8$ & $432 \pm 9$ & $389 \pm 14$ & $387 \pm 15$ & $403 \pm 16$ \\
\hline Heart weight (mg) & $1165 \pm 30$ & $1243 \pm 80$ & $1406 \pm 41 *$ & $1533 \pm 57^{*}$ & $1488 \pm 55^{*}$ \\
\hline $\begin{array}{l}\text { Relative heart weight } \\
(\mathrm{mg} / 100 \mathrm{~g} \mathrm{BW})\end{array}$ & $285 \pm 7$ & $286 \pm 15$ & $363 \pm 5^{*}$ & $397 \pm 8 * @$ & $372 \pm 16^{*}$ \\
\hline Kidney weight (mg) & $3010 \pm 80$ & $3487 \pm 145$ & $2971 \pm 118$ & $3408 \pm 110$ & $3496 \pm 137^{@}$ \\
\hline $\begin{array}{l}\text { Relative kidney weight } \\
(\mathrm{mg} / 100 \mathrm{~g} \mathrm{BW})\end{array}$ & $738 \pm 18$ & $806 \pm 25$ & $765 \pm 13$ & $885 \pm 20 * @$ & $869 \pm 22 * @$ \\
\hline
\end{tabular}

\section{THERAPEUTIC STUDY}

Data are means \pm SEM. Significantly different: $* p<0.05$ vs. HanSD, ${ }^{\circledR} p<0.05$ vs. TGR on normal salt diet. 
PREVENTIVE STUDY THERAPEUTIC STUDY
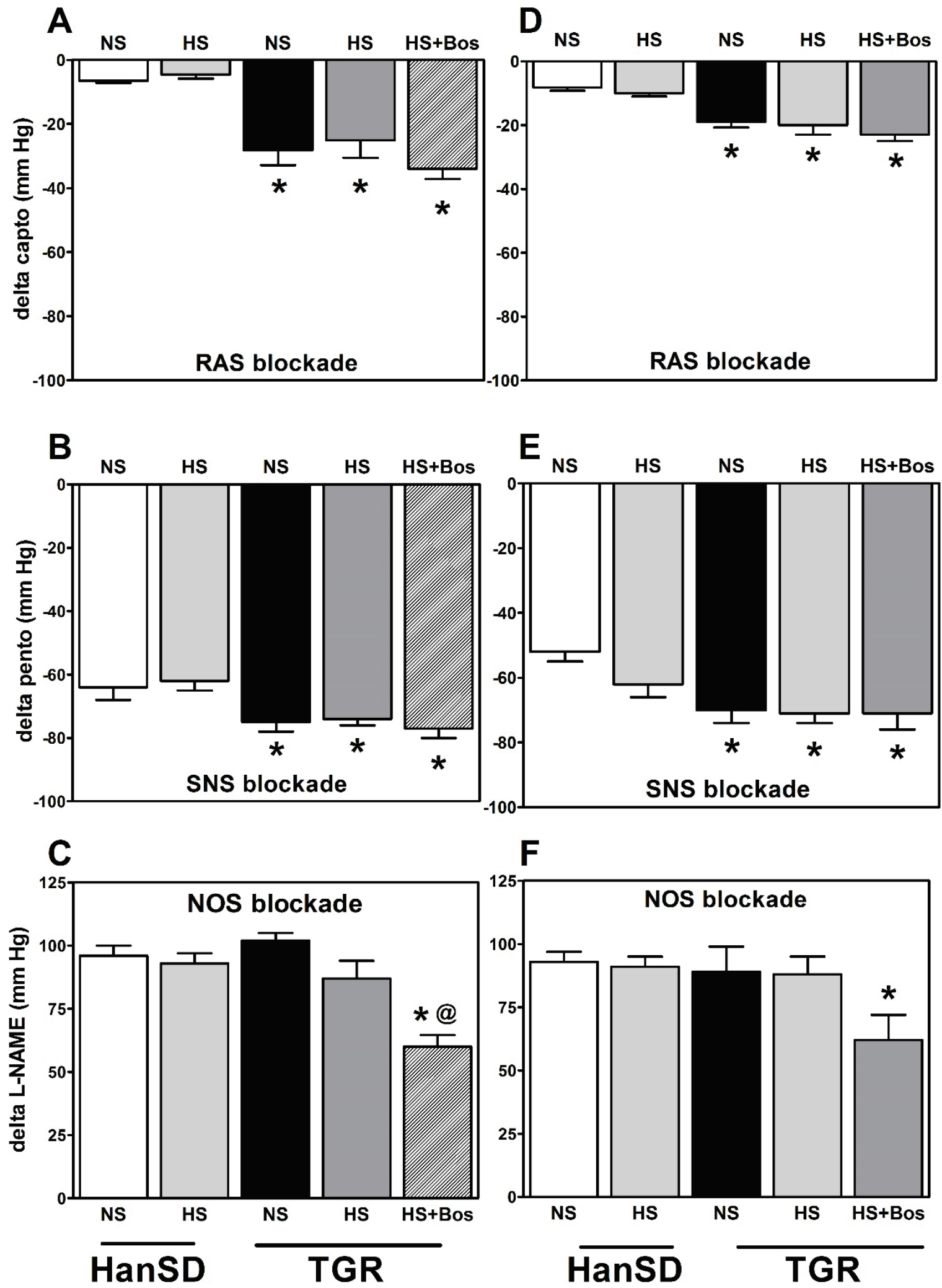

Fig. 2. The participation of major vasoactive systems contributing to BP maintenance - angiotensin II-dependent vasoconstriction (RAS blockade) (A, D), sympathetic vasoconstriction (SNS blockade) (B, E) and nitric oxide-dependent vasodilation (NOS blockade) (C, F). MAP changes were recorded at the end of the experiment in conscious young (preventive study) (A-C) and adult (therapeutic study) (D-F) normotensive control Hannover Sprague Dawley (HanSD) and hypertensive heterozygous Ren-2 transgenic rats (TGR) on normal salt (NS) diet, high-salt (HS) diet, or HS diet treated with nonselective $\mathrm{ET}_{\mathrm{A}} / \mathrm{ET}_{\mathrm{B}}$ receptor antagonist bosentan (Bos). The data are the means \pm SEM. $* p<0.05$ vs. control HanSD rats, ${ }^{\circledR} p<0.05$ vs. TGR on normal salt diet. 
PREVENTIVE STUDY

\section{A}

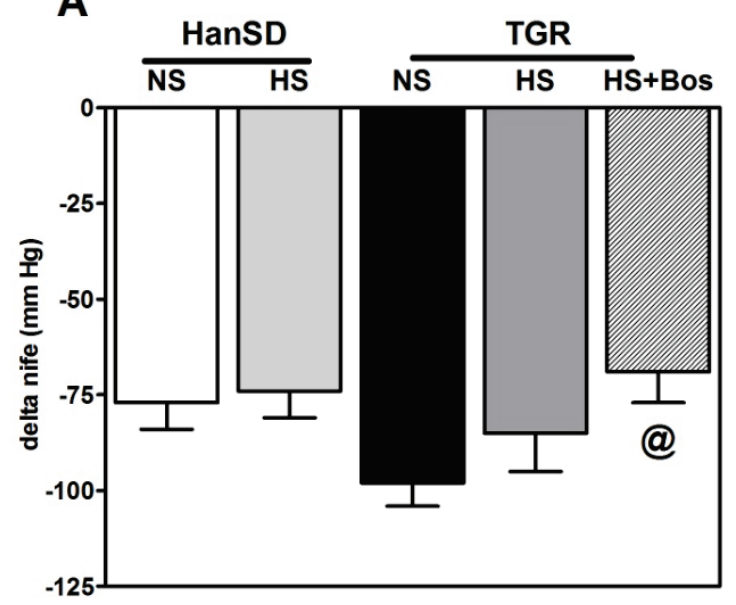

THERAPEUTIC STUDY

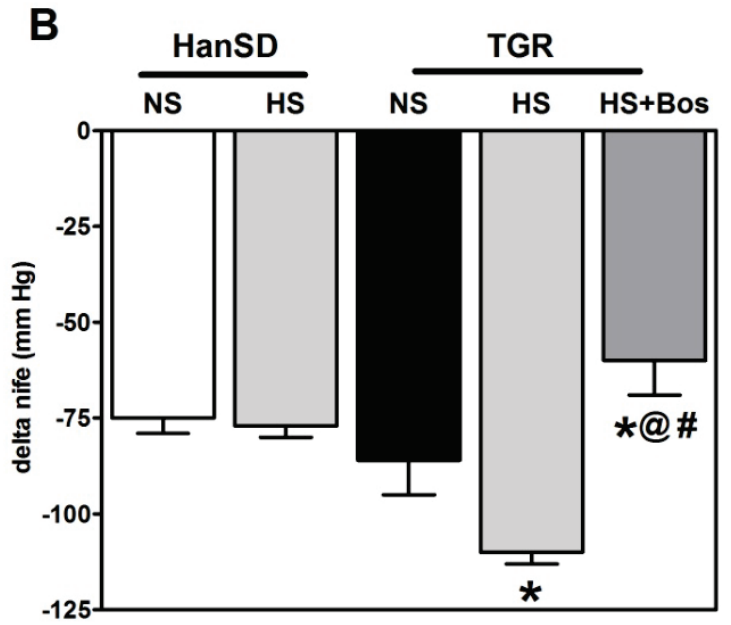

Fig. 3. Nifedipine-induced BP reduction elicited by the inhibition of calcium influx through the voltage-dependent calcium channels (L-VDCC) in young (preventive study) (A) and adult (therapeutic study) (B) normotensive control Hannover Sprague Dawley (HanSD) and hypertensive heterozygous Ren-2 transgenic rats (TGR) on normal salt (NS) diet, high-salt (HS) diet, or HS treated with nonselective $\mathrm{ET}_{\mathrm{A}} / \mathrm{ET}_{\mathrm{B}}$ receptor antagonist bosentan (Bos). The data are the means $\pm \mathrm{SEM}$. ${ }^{*} \mathrm{p}<0.05$, vs. control HanSD rats, ${ }^{@} \mathrm{p}<0.05$ vs. TGR on normal salt diet, ${ }^{*} \mathrm{p}<0.05$ vs. TGR on high-salt diet.

\section{PREVENTIVE STUDY}

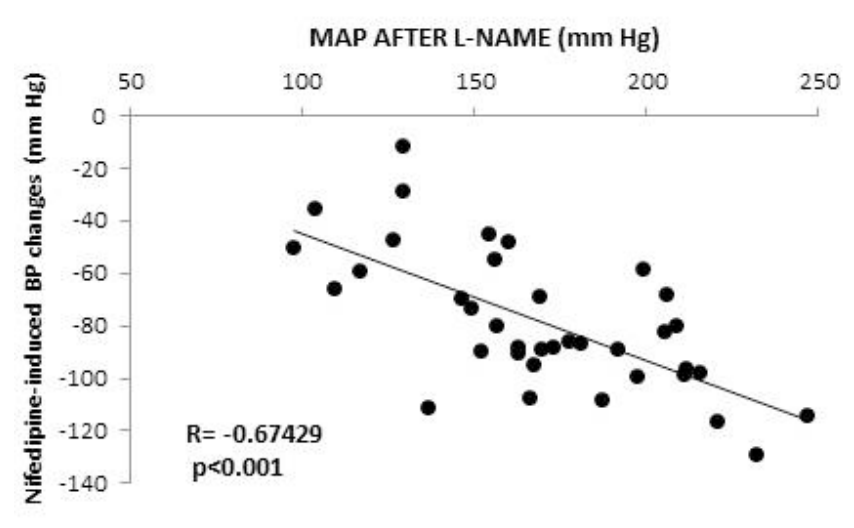

\section{THERAPEUTIC STUDY}



Fig. 4. The correlation of mean arterial pressure after complete vasoactive blockade (captopril, pentolinium and L-NAME) with MAP response to nifedipine-induced inhibition of calcium influx through the voltage-dependent calcium channels (L-VDCC) in young (preventive study) (left panel) and adult (therapeutic study) (right panel) rats.

\section{Discussion}

Our study demonstrated that i) high-salt intake did not aggravate hypertension development in TGR rats, ii) their high BP is dependent on different vasoconstrictor systems in young and adult hypertensive rats, iii) although bosentan had no effect on blood pressure and hence on the major vasoconstrictor systems contributing to BP maintenance, it significantly decreased NO-dependent vasodilation and nifedipine-sensitive calcium influx through the voltage-dependent calcium channels.
The blood pressure of hypertensive heterozygous male TGR was significantly higher in young rats than in the adults. This finding is quite intriguing since this phenomenon - decreasing BP with advancing age - was typically described for female TGR (Cargnelli et al. 1998, Vaněčková et al. 2011) but only rarely for aged male TGR (Kasper et al. 2005). A high salt intake did not influence the blood pressure level either in the preventive or in the therapeutic study, suggesting that young heterozygous TGR animals are not more sensitive to the increased sodium intake.

We confirmed our previous findings (Vaněčková 
et al. 2012) that the contribution of major vasoconstrictor systems to high blood pressure in heterozygous TGR is age-dependent - RAS-dependent vasoconstriction being the leading system in young animals while the sympathetic-vasoconstriction prevailed with advancing age.

The fact that we did not observe any blood pressure lowering effect of nonselective endothelin receptor antagonist bosentan in Ren-2 transgenic rats is not unexpected since both our study and others did not shown any substantial blood pressure decrease either in heterozygous (Andreis et al. 2000, Vaněčková et al. 2006, Vernerová et al. 2008) or in homozygous rats (Vaněčková et al. 2005, Opočenský et al. 2006). In this context, it is also not surprising that no changes in the contribution of major vasoconstrictor systems following bosentan treatment were observed in the present study.

By contrast, a substantial decrease of L-NAMEinduced NO-dependent vasorelaxation was discerned in bosentan-treated salt-loaded TGR, which is a finding similar to that seen with a selective endothelin receptor $\mathrm{A}$ antagonist atrasentan in our previous study (Vaněčková et al. 2015). While the reduction of NO-dependent vasodilation is understandable in the present study with bosentan, having in mind that $\mathrm{ET}_{\mathrm{B}}$ receptors mediate the endothelin effects on nitric oxide and cyclooxygenase production, the same finding with a selective $\mathrm{ET}_{\mathrm{A}}$ blockade was rather surprising. We cannot offer a satisfactory explanation for this finding but one should consider a possible interaction of both receptors, which has been recently described by Vercauteren et al. (2017). These authors demonstrated that for fluid retention encountered during an endothelin $\mathrm{ET}_{\mathrm{A}}$ receptor blockade, the increased vascular permeability resulting from the concurrent activation of $\mathrm{ET}_{\mathrm{B}}$ receptors is responsible.

There was a significantly attenuated nifedipinesensitive calcium influx through L-VDCC in TGR on high-salt diet treated with bosentan. A similar decrease, although more prominent was reported in salt-loaded TGR rats subjected to atrasentan treatment (Vaněčková et al. 2015). Our previous assumption that this is associated with a higher activation of endothelin-induced calcium influx due to high salt intake could be excluded since this was true only in the therapeutic study but not in the prevention study. Our correlation analysis revealed that a nifedipine-induced BP change correlates strongly with the basal BP, a phenomenon that has been reported for other hypertensive strains (Zicha et al. 2014). However, when the salt-loaded TGR subjected to bosentan treatment was added, the correlation was attenuated. In addition, a highly important correlation of nifedipine-induced BP change was also observed for the BP after L-NAME administration, thus suggesting a major role of nitric oxide in the closure of L-type voltage dependent calcium channels.

In conclusion, the selective or nonselective endothelin receptor antagonists share important similarities which are independent of blood pressure, both groups affecting NO-dependent vasodilation and calcium influx through L-type voltage-dependent calcium channels.

\section{Conflict of Interest}

There is no conflict of interest.

\section{Acknowledgements}

The technical assistance of Zdeňka Kopecká and Alena Charvátová is highly appreciated. This study was supported by the Institute of Physiology, Czech Academy of Sciences (grant Nr. RVO 67985823), by the Ministry of Health of the Czech Republic (grant Nr. 15-25396A) and partially by the Bilateral mobility project of the Czech Academy of Sciences and the Polish Academy of Sciences (PAN-17-13). The authors are grateful to Mr. Robert Kotanchik for his help in editing the manuscript.

\section{References}

ANDREIS PG, REBUFFAT P, NERI G, ROSSI GP, NUSSDORFER GG: Effects of irbesartan and bosentan on the blood pressure and adrenal zona glomerulosa function in heterozygous transgenic TGR[mREN2]27 rats. Life Sci 67: 543-547, 2000.

ALLCOCK GH, VENEMA RC, POLLOCK DM: ET $\mathrm{A}$ receptor blockade attenuates the hypertension but not renal dysfunction in DOCA-salt rats. Am J Physiol 275: R245-R252, 1998.

BARTON M, D'USCIO LV, SHAW S, MEYER P, MOREAU P, LUSCHER TF: ETA receptor blockade prevents increased tissue endothelin-1, vascular hypertrophy, and endothelial dysfunction in salt-sensitive hypertension. Hypertension 31: 499-504, 1998. 
CARGNELLI G, ROSSI GP, PESSINA AC, LUCIANI S, DEBETTO P, GANTEN D, PETERS J, BOVA S: Changes of blood pressure and aortic strip contractile responses to ET-1 of heterozygous female transgenic rats, TGR(mRen2)27. Pharmacol Res 37: 207-211, 1998.

DING SS, QIU C, HESS P, XI JF, ZHENG N, CLOZEL M: Chronic endothelin receptor blockade prevents both early hyperfiltration and late overt diabetic nephropathy in the rat. J Cardiovasc Pharmacol 42: 48-54, 2003.

DVOŘÁK P, KRAMER HJ, BÄCKER A, MALÝ J, KOPKAN L, VANĚČKOVÁ I, VERNEROVÁ Z, OPOČENSKÝ M, TESA ̌ V, BADER M, GANTEN D, JANDA J, ČERVENKA L: Blockade of endothelin receptors attenuates end-organ damage in homozygous hypertensive ren-2 transgenic rats. Kidney Blood Press Res 27: $248-258,2004$.

HERRERA M, GARVIN JL: A high-salt diet stimulates thick ascending limb eNOS expression by raising medullary osmolality and increasing release of endothelin-1. Am J Physiol Renal Physiol 288: F58-F64, 2005.

KASPER SO, CARTER CS, FERRARIO CM, GANTEN D, FERDER LF, SONNTAG WE, GALLAGHER PE, DIZ DI: Growth, metabolism, and blood pressure disturbances during aging in transgenic rats with altered brain renin-angiotensin systems. Physiol Genomics 23: 311-317, 2005.

KOHAN DE: Endothelin and collecting duct sodium and water transport. Contrib Nephrol 172: 94-106, 2011.

LI JS, KNAFO L, TURGEON A, GARCIA R, SCHIFFRIN EL: Effect of endothelin antagonism on blood pressure and vascular structure in renovascular hypertensive rats. Am J Physiol 271: H88-H93, 1996.

MATSUMURA Y, HASHIMOTO N, TAIRA S, KURO T, KITANO R, OHKITA M, OPGENORTH TJ, TAKAOKA M: Different contributions of endothelin-A and endothelin-B receptors in the pathogenesis of deoxycorticosterone acetate-salt-induced hypertension in rats. Hypertension 33: 759-765, 1999.

MULLER DN, MERVAALA EM, SCHMIDT F, PARK JK, DECHEND R, GENERSCH E, BREU V, LÖFFLER BM, GANTEN D, SCHNEIDER W, HALLER H, LUFT FC: Effect of bosentan on NF-kB, inflammation, and tissue factor in angiotensin II-induced end-organ damage. Hypertension 36: 282-290, 2000.

MULLINS JJ, PETERS J, GANTEN D: Fulminant hypertension in transgenic rats harbouring the mouse Ren-2 gene. Nature 344: 541-544, 1990.

OKADA M, KOBAYASHI M, MARUYAMA H, TAKAHASHI R, IKEMOTO F, YANO M, NISHIKIBE M: Effects of a selective endothelin A-receptor antagonist, BQ-123, in salt-loaded stroke-prone spontaneously hypertensive rats. Clin Exp Pharmacol Physiol 22: 763-768, 1995.

OKADA M, NISHINO M, SAITO M, IKEDA T, UEHARA S, OKADA H, NIIYAMA K, OHTAKE N, HAYAMA T, NISHIKIBE M: Marked reduction of mortality in salt-loaded Dahl salt-sensitive rats by the new, selective endothelin $\mathrm{ET}_{\mathrm{A}}$ receptor antagonist, J-105859. J Hypertens 18: 1815-1823, 2000.

OPOČENSKÝ M, DVOŘÁK P, MALÝ J, KRAMER HJ, BÄCKER A, KOPKAN L, VERNEROVÁ Z, TESAŘ V, ZIMA T, BADER M, GANTEN D, JANDA J, VANEČKOVÁ I: Chronic endothelin receptor blockade reduces end-organ damage independently of blood pressure effects in salt-loaded heterozygous Ren-2 transgenic rats. Physiol Res 53: 581-593, 2004.

OPOČENSKÝ M, KRAMER HJ, BÄCKER A, VERNEROVÁ Z, EIS V, ČERVENKA L, ČERTÍKOVÁ CHÁBOVÁ V, TESAŘ V, VANĚČKOVÁ I: Late-onset endothelin-A receptor blockade reduces podocyte injury in homozygous Ren-2 rats despite severe hypertension. Hypertension 48: 965-971, 2006.

ROSSI GP, SACCHETTO A, RIZZONI D, BOVA S, PORTERI E, MAZZOCCHI G, BELLONI AS, BAHCELIOGLU M, NUSSDORFER GG, PESSINA AC: Blockade of angiotensin II type 1 receptor and not of endothelin receptor prevents hypertension and cardiovascular disease in transgenic (mREN2)27 rats via adrenocortical steroid-independent mechanisms. Arterioscler Thromb Vasc Biol 20: 949-956, 2000.

ROTHERMUND L, KOSSMEHL P, NEUMAYER HH, PAUL M, KREUTZ R: Renal damage is not improved by blockade of endothelin receptors in primary renin-dependent hypertension. J Hypertens 21: 2389-2397, 2003.

SCHIFFRIN EL, LARIVIÈRE R, LI JS, SVENTEK P: Enhanced expression of the endothelin-1 gene in blood vessels of DOCA-salt hypertensive rats: correlation with vascular structure. J Vasc Res 33: 235-248, 1996.

VANĚČKOVÁ I, KRAMER HJ, BÄCKER A, VERNEROVÁ Z, OPOČENSKÝ M, ČERVENKA L: Early endothelinA receptor blockade decreases blood pressure and ameliorates end-organ damage in homozygous Ren-2 rats. Hypertension 46: 969-974, 2005. 
VANĚČKOVÁ I, KRAMER HJ, BÄCKER A, SCHEJBALOVÁ S, VERNEROVÁ Z, EIS V, OPOČENSKÝ M, DVOŘÁK P, ČERVENKA L: Early-onset endothelin receptor blockade in hypertensive heterozygous Ren-2 rats. Vascul Pharmacol 45: 163-170, 2006.

VANĚČKOVÁ I, HUSKOVÁ Z, VAŇOURKOVÁ Z, ČERVENKA L: Castration has antihypertensive and organoprotective effects in male but not in female heterozygous Ren-2 rats. Kidney Blood Press Res 34: 46-52, 2011.

VANĚČKOVÁ I, DOBEŠOVÁ Z, KUNEŠ J, ZICHA J: The effects of repeated delivery of angiotensin II AT(1) receptor antisense on distinct vasoactive systems in Ren-2 transgenic rats: young vs. adult animals. Hypertens Res 35: 761-768, 2012.

VANĚČKOVÁ I, DOBEŠOVÁ Z, KUNEŠ J, VERNEROVÁ Z, ZICHA J: Endothelin A receptor blocker atrasentan lowers blood pressure by the reduction of nifedipine-sensitive calcium influx in Ren-2 transgenic rats fed a high-salt diet. J Hypertens 33: 161-169, 2015.

VANĚČKOVÁ I, ŘEZÁČOVÁ L, KUNEŠ J, ZICHA J: Moderate additive effects of endothelin receptor A blockade in Ren-2 transgenic rats subjected to various types of RAS blockade. Life Sci 159: 127-134, 2016.

VANĚČKOVÁ I, HOJNÁ S, KADLECOVÁ M, VERNEROVÁ Z, KOPKAN L, ČERVENKA L, ZICHA J. Renoprotective effects of ET(A) receptor antagonists therapy in experimental non-diabetic chronic kidney disease: Is there still hope for the future? Physiol Res 67 (Suppl 1): S55-S67, 2018.

VERCAUTEREN M, TRENSZ F, PASQUALI A, CATTANEO C, STRASSER DS, HESS P, IGLARZ M, CLOZEL M: Endothelin ET(A) receptor blockade, by activating ET(B) receptors, increases vascular permeability and induces exaggerated fluid retention. J Pharmacol Exp Ther 361: 322-333, 2017.

VERNEROVÁ Z, KRAMER HJ, BÄCKER A, ČERVENKA L, OPOČENSKÝ M, HUSKOVÁ Z, VAŇOURKOVÁ Z, EIS V, CHÁBOVÁ VC, TESAR̆ V, MALÝ J, VANĚČKOVÁ I: Late-onset endothelin receptor blockade in hypertensive heterozygous REN-2 transgenic rats. Vascul Pharmacol 48: 165-173, 2008.

ZICHA J, KUNEŠ J: Ontogenetic aspects of hypertension development: analysis in the rat. Physiol Rev 79: 1227-1282, 1999.

ZICHA J, KUNEŠ J, JELÍNEK J: Experimental hypertension in young and adult animals. Hypertension 8: 1096-1104, 1986.

ZICHA J, DOBEŠOVÁ Z, KUNEŠ J, VANĚČKOVÁ I: Chronic endothelin A receptor blockade attenuates contribution of sympathetic nervous system to salt hypertension development in adult but not in young Dahl rats. Acta Physiol (Oxf) 205: 124-132, 2012.

ZICHA J, DOBEŠOVÁ Z, BEHULIAK M, PINTÉROVÁ M, KUNEŠ J, VANĚČKOVÁ I: Nifedipine-sensitive blood pressure component in hypertensive models characterized by high activity of either sympathetic nervous system or renin-angiotensin system. Physiol Res 63: 13-26, 2014. 